\begin{tabular}{|c|c|c|c|c|}
\hline JURNAL & \multirow{2}{*}{ VOLUME 1 } & \multirow{2}{*}{ NOMOR 2 } & HALAMAN 70-141 & $\begin{array}{l}\text { ISSN 2655-8823 }(p) \\
\text { ISSN 2656-1786 }(e)\end{array}$ \\
KOLABORASI RESOLUSI KONFLIK & H
\end{tabular}

\title{
KONFLIK KEPENTINGAN LAHAN WARGA RW 11 TAMANSARI DENGAN PEMERINTAH KOTA BANDUNG DALAM KASUS REALISASI PROGRAM RUMAH DERET
}

\author{
Ali Ar-Ridho \\ Mahasiswa Program Studi Sarjana Kesejahteraan Sosial FISIP UNPAD \\ E-mail: ridhoolife@gmail.com \\ Ishartono \\ Dosen Program Studi Sarjana Kesejahteraan Sosial FISIP UNPAD \\ E-mail: $\underline{\text { ishartono,kesos@gmail.com }}$
}

\begin{abstract}
ABSTRAK
Konflik merupakan sebuah fenomena yang lazim terjadi di masyarakat, baik dalam tatanan ruang lingkup mikro, mezzo maupun makro, konflik akan selalu ada sebagai penanada adanya kehidupan masyarakat yang dinamis. Konflik itu sendiripun dapat berwujud kedalam beberapa bentuk masalah dan salah satunya adalah konflik sengketa lahan atau lebih dikenal dengan konflik agraria. Konflik agraria merupakan satu sub-bahasan dari studi konflik yang cukup banyak terjadi dan salah satunya yang terjadi di jawa barat adalah konflik sengketa lahan warga tamansari RW 11 dengan pemerintah kota bandung. Konflik ini merupakan sebuah masalah yang terjadi dikarenakan adanya ketidaksepahaman dan ketidaksepakatan diantara warga RW 11 tamansari dengan pemerintah kota bandung dalam pembangunan rumah deret yang termasuk kedalam program pemerintah daerah untuk merealisasikan kota bandung bebas pemukiman kumuh tahun 2019. Konflik ini telah banyak melalui proses mediasi hingga hukum yang pada akhirnya dimenangkan oleh pemerintah kota bandung. Tulisan ini bermaksud untuk mengkaji masalah ini berdasarkan teori struktural dan kekuasaan dalam kajian sosiologi.
\end{abstract}

Kata kunci: Konflik, konflik lahan, warga, pemerintah, rumah deret.

\section{PENDAHULUAN}

Kota bandung merupakan sebuah kota yang banyak dijadikan destinasi kota wisata baik turis domestik maupun internasional yang terkenal dengan keindahan dan kerapihannya dalam aspek tata ruang kota. Namun, di kota bandung masih terdapat sekitar lima ribu hektare pemukiman kumuh yang diantaranya termasuk RW 11 Tamansari. Tamansari merupakan sebuah kawasan yang berada di pusat kota, lebih tepatnya di kawasan dago yang juga berdekatan dengan cihampelas. Tamansari juga tergolong lokasi yang strategis karena diapit dengan beberapa perguruan tinggi seperti ITB dan Unisba serta dengan lokasi pusat perbelanjaan. Namun demikian, tamansari termasuk kedalam golongan pemukiman kumuh yang menjadi target penertiban lahan oleh pemerintah kota bandung yang nantinya akan dibuatkan rumah deret untuk menggantikan perumahan warga yang sangat padat dan tidak teratur. Program rumah deret inilah yang menjadi objek permasalahan sengketa lahan diantara warga dengan pemerintah kota bandung.

Dalam keterangannya, pemerintah kota badnung menginginkan terciptanya kota bandung yang terbebas dari lahan kumuh dengan mekanisme yang telah direncanakan, namun pada implementasinya terjadi banyak pertentangan dengan warga karena pemerintah dianggap melakukan intervensi sepihak dan tidak memberikan sosialisasi yang memadai kepada masyarakat terdampak. Hal inilah yang kemudian menjadikan konflik ini masalah yang berkepanjangan. Pada awalnya, warga terdampak menerima dengan terbuka program ini, namun, seiring denga berjalannya waktu program ini menuai protes dikarenakan warga banyak menemukan kejanggalan dalam proses sosialiasi terutama pada proses kejelasan 


\begin{tabular}{|c|c|c|c|c|}
\hline JURNAL & \multirow{2}{*}{ VOLUME 1 } & NOMOR 2 & HALAMAN 70-141 & $\begin{array}{l}\text { ISSN 2655-8823 }(p) \\
\text { ISSN 2656-1786 }(e)\end{array}$ \\
\hline KOLABORASI RESOLUSI KONFLIK & H
\end{tabular}

mekanisme ganti rugi lahan, relokasi sementara dan pasca pembangunan selesai.

Warga menilai pemerintah kota bandung merampas hak-hak atas tanah mereka yang sudah ditempati puluhan tahun. Perlu diketahui bahwa tanah yang ditempati oleh warga tamansari merupkan tanah yang sebagian besar belum bersertifikat dan baru dimulai diusahakan pengadaan sertifikat tanah oleh pemerintah kota bandung diawal tahun 2016. Hal yang menjadi protes warga adalah bahwa pemerintah menyamaratakan perlakuan tanah yang sudah bersertifikat dan yang belum selesai proses sertifikasinya. Pemerintah kota bandung hanya menawarkan solusi jangka pendek dan panjang yang terkesan sangat dipaksakan karena tidak melibatkan warga dalam perumusannya. Hal inilah yang kemudian akan dibahas pada tulisan ini yang berfokus pada masalah komunikasi pemerintah kota bandung dan warga taman sari RW 11 dengan pendekatan teori struktural dan kekuasaan.

\section{TINJAUAN PUSTAKA}

Pada kajian konflik ini menggunakan teori konflik struktural dan kekuasaan yang dicetuskan oleh Karl Max yang menyatakan bahwa terjadinya sebuah perubahan/konflik di masyarakat merupakan akibat dari superiaritas pemegang kekuasaan yang mampu menggerakan masyarakat yang termasuk kedalam kekuasaannya untuk menciptakan kondisi yang diinginkan. Dalam teori ini mengganggap bahwa munculnya konfli di masyarakat merupakan akibat dari penyalahgunaan kekuasaan pemerintah. Hal ini dikarenakan pemerintah memiliki kekuasaan penuh atas kebijakan yang seharusnya dapat lebih memperhatikan aspek kepentingan masyarakat banyak. Teori selanjutnya adalah teori kekuasaan yang juga dicetuskan oleh marx. Teori ini mengatakab bahwa pemegang kekuasaan adalah pihak yang paling bertanggung jawab atas konflik yang terjadi di masyarakat. Dapat dikatakan bahwa pemegang kekuasaan memiliki kekuatan besar untuk menggerakan masyarakat untuk mengikuti perubahan yang diinginkan beserta tingkah laku dan kebiasaannya. Kedua teori inilah yang akan menjadi pendekatan dalam telaah masalah dalam penulisan ini.

\section{METODE PENELITIAN}

Penelitian bertujuan untuk memberikan pengetahuan baru kepada pembaca tentang melihat konflik dari perspektif pemerintah dan masyarakat. Pada tulisan ini menggunakan metode penelitian studi Literatur yang mana penulis menghimpun informasi mengenai masalah yang akan dibahas di dalam penelitian ini dari berbagai referensi seperti buku, jurnal, buku serta sumber lain yang relevan yang dengan isu yang dikaji serta tujuan dari penelitian. Dengan menggunakan teknik ini diharapkan dapat menghasilkan kajian yang komprehensif dan relewan dengan masalah yang akan di teliti sebagai bahan rujukan dalam pembahasan hasil penelitian.

\section{HASIL DAN PEMBAHASAN \\ Pemicu, Penyebab, dan Dampak Konflik}

Seperti yang sudah diterangkan di bagian pendahuluan, konflik ini bermula ketika pemerintah kota bandung yang mulai merealisasikan program bandung bebas kumuh 2019 di kawasan padat penduduk RW 11 tamansari, bandung. Konflik disebabkan oleh pemerintah kota bandung yang dianggap secara sepihak menjalankan program serta mekanisme ganti rugi yang sangat tidak sepadan dengan resiko yang akan diterima warga akibat penggusuran. Dalam keterangannya, pemerintah kota bandung tidak menganggap program ini sebagai program yang menggusur karena pemerintah memberikan ganti rugi berupa berupa uang tunai dari $20 \%$ NJOP, pembiayaan sewa sebesar 250.000 rupiah selama masa pembangunan dan pembebasan biaya sewa selama lima tahun setelah pembangunan rampung. Kebijakan 


\begin{tabular}{|c|c|c|c|c|}
\hline JURNAL & \multirow{2}{*}{ VOLUME 1 } & NOMOR 2 & HALAMAN 70-141 & $\begin{array}{l}\text { ISSN 2655-8823 }(p) \\
\text { ISSN 2656-1786 }(e)\end{array}$ \\
\hline KOLABORASI RESOLUSI KONFLIK
\end{tabular}

inilah yang kemudian menjadi polemik karena dianggap sangat rendah dan tidak sepadan dengan resiko kehilangan yang diterima oleh warga dilihat dari kondisi biaya hidup kota bandung.

Sebagian besar masyarakat menolak kebijakan ini dengan melakukan negosiasi dengan pemerintah kota untuk menaikkan penggantian NJOP hingga 70\%. Proses ini berlangsung cukup lama, dan pada proses ini banyak warga yang pada akhirnya memilih untuk mengalah menghindari konflik dan menerima apa yang diberikan oleh pemrintah kota bandung. Namun bagi warga yang tidak setuju tetap memperjuangkan kelayakan ganti rugi atau bahkan tidak mau meninggalkan tempat tinggalnya sama sekali. Berbagai langkah telah ditempuh oleh warga mulai dari bantuan advokasi LBH dan Mahasiswa namun tak kunjung terdapat kesepakatan. Bahkan pemerintah kota bandung beberapa kali mengerahkan polisi untuk meredam unjuk rasa warga yang disinyalir juga melakukan kekerasan kepada warga. Menurut penuturan warga, konflik ini sebenarnya tidak akan begitu meuncung jika pemerintah memberikan sosialisasi yang menyeluruh kepada warga dan melibatkan warga dalam perumusan skema ganti rugi. Dalam hal ini warga menilai pemerintah terkesan tergesa-gesa sehingga melupakan partisipasi warga. Kemudian karena alasan inilah yang memicu kekhawatiran/ketakutan warga yang akhirnya menimbulkan konflik. Warga merasa diteror oleh pemerintah yang terus memberikan tenggat waktu kepada warga untuk meninggalkan lokasi. Adapun akibat dari konflik ini adalah 198 kepala keluarga harus menghadapi konflik berkepanjangan serta beberapa orang menerima tindak kekerasan dari aparat keamanan. Adapun tipe konflik yang terjadi pada masalah ini adalah konflik permukaan karena konflik ini terjadi atas kesalahpahaman dan kurangefektifnya komunikasi diantara pemerintah dan warga serta konflik vertikal karena dalam masalah ini terjadi konflik diantara pemerintah sebagai pemegang kekuasaan dan warga sebagai masyarakat.

\section{Analisa Pendekatan Resolusi Konflik}

Dalam permasalahan ini, pendekatan yang banyak dilakukan baik oleh pihak pemerintah kota bandung dan warga adalah mediasi meski pada akhirnya pemerintah menggunakan cara represif dan jalur hukum untuk memenangkan lahan RW 11 Tamansari. Pada awalnya pemerintah memang tidak begitu memperhatikan partisipasi warga dalam perumusan skema ganti rugi, warga hanya disodorkan solusi yang tidak mereka ketahui alasan rasional apa yang kemudian mendasari skema ganti rugi tersebut. Meski demikian warga RW 11 tamansari sangat mengusahakan untuk mendapatkan ganti rugi yang lebih baik. Namun seiring waktu berjalan banyak warga yang lebih memilih mundur dari usaha ini yang kemudian menjadikan pemerintah memliki kekuatan lebih untuk merealisasikan program. Program harus tetap dijalankan namun masih banyak warga yang memilih untuk tetap memperjuangkan ganti rugi yang lebih layak atau bahkan tidak mau direlokasi sama sekali. Pada kondisi ini akhirnya pemerintah banyak mengintervensi masalah ini lewat jalur hukum yang kemudian dimenangkan oleh pemerintah sekalipun warga telah mengajukan banding.

\section{Peran Pekerja Sosial dalam Menangani Konflik}

Adapun peran pekerja sosial yang dapat dilakukan dalam konflik ini adalah peran advokat dan mediator diantara pemerintah dan warga, khususnya dalam hal mempengaruhi pemerintah dalam perumusan kebijakan ganti rugi. Pekerja sosial juga dapat menjalankan perannya sebagai pendamping masyarakat dalam mengajukan banding kepada pemerintah dengan ilmu dan pengetahuan yang lebih mumpuni untuk menghindarkan warga dari kebijakan pemerintah yang tidak pro 


\begin{tabular}{|c|c|c|c|c|}
\hline JURNAL & \multirow{2}{*}{ VOLUME 1 } & NOMOR 2 & HALAMAN 70-141 & $\begin{array}{l}\text { ISSN 2655-8823 }(p) \\
\text { ISSN 2656-1786 }(e)\end{array}$ \\
\hline KOLABORASI RESOLUSI KONFLIK & H
\end{tabular}

rakyat. Pekerja diharapkan mampu untuk menjadi penyambung celah konflik diantara warga dan pemerintah. Hal ini dikarenakan pemerintah yang sudah mempunyai itikad baik dalam pengelolaan lahan kumuh yang akan dijadikan pemukiman yang lebih layaj untuk ditinggali, namun di satu sisi pemerintah gagal dalam memberikan ruang partisipasi untuk warga dalam perumusah skema ganti rugi. Di sisi warga juga menginginkan ganti rugi yang lebih layak dan rasional namun gugatan mereka banyak terhenti karena minimnya ilmu terkait konflik. Disinilah pekerja sosial dapat berperan dalam meperbaiki relasi antara pemerintah dan masyarakat dengan menekan dampak konfliknya serendah mungkin.

\section{KESIMPULAN DAN SARAN Kesimpulan}

Pada dasarnya, konflik merupakan fenomena yang akan terus selalu ada seiring dengan berkembangnya zaman serta kebijakannya. Konflik semakin tidak terhindari ketika dua atau lebih kepentingan bertemu dan memperjuangkan tujuannya masingmasing tanpa memperhatikan keadaan pihak lain. Adapun kesimpulan dalam kasus ini adalah konflik terjadi karena program pemerintah yang sudah terencana baik namun tidak tersosialisasikan dengan sempurna, hal inilah yang kemudian memicu konflik berkepanjangan diantara pemerintah. Adapun hal yang lebih mendasar adalah faktor superioritas pemerintah yang menganggap mereka lebih mengetahui apa yang harus dilakukan hingga melupakan konsekuensi yang dirasakan langsung oleh masyarakat terdampak. Pada kasus ini dapat disimpulkan bahwa program yang baik belum tentu akan berjalan dengan baik bila sosialsasi tidak dilakukan dengan baik

\section{Saran}

Terdapat banyak konflik yang sebetulnya tidak perlu terjadi apabila terjalin komunikasi yang baik dan sehat diantara kedua pihak yang terlibat. Berkaca pada konflik pembangunan rumah deret yang melibatkan warga dan pemerintah kota bandung ini dapat diambil benang merah bahwa sebuah kesalahan informasi dapat menyebabkan konflik yang cukup besar. Adapun saran yang ingin penulis sampaikan khususnya bagi pekerja sosial adalah untuk meningkatkan sensitivitas mereka terhadap isu-si atau masalah yang sebenarnya hanya terjadi karena hal yang sepele namun berakibat fatal. Diharapkan pekerja sosial mampu menganalisa sebuah permasalahan dengan baik dan mengetahui sebab terjadinya masalah hingga pada analisa yang paling tidak terduga.

\section{DAFTAR PUSTAKA}

Ispranoto, Tri. 2017. Penjelasan Pemkot Bandung Soal Penggusuran di Tamansari. Diunduh dari https://news.detik.com/berita-jawabarat/d-3691035/penjelasan-pemkotbandung-soal-penggusuran-ditamansari

Nugraha, Arie. 2017. PTUN Bandung Tolak Gugatan Warga Tamansari Tentang Rumah Deret. Diunduh dari https://kumparan.com/bandungkiwari/ ptun-tidak-kabulkan-gugatan-wargatamansari-terhadap-rumah-deret

Rosadi, Dian. 2018. 198 kepala keluarg RW 11 setuju pembangunan rumah deret Tamansari Bandung. Diunduh dari

https://bandung.merdeka.com/halobandung/198-kepala-keluarg-rw-11setuju-pembangunan-rumah-derettamansari-bandung--1803209.html

Fachmi, Rafi. 2018. Menggugat Pembangunan Rumah Deret yang Cacat Prosedur. Diunduh dari http://suakaonline.com/12095/2018/02 /07/menggugat-pembangunan-rumahderet-yang-cacat-prosedur/ 
JURNAL

Satrio, Ilham. 2017. Yang Diabaikan dan

Dilanggar di Tamansari Bandung.

Diunduh dari

http://metaruang.com/yang-diabaikandan-dilanggar-di-tamansari-bandung/ 